\title{
TALKING POINTS
}

\section{Women doctors in training: problems and progress}

\section{A J SWERDLOW, R H MCNEILLY, E ROSEMARY RUE}

\section{Introduction}

As the number of women doctors has grown so their careers and career problems have become increasingly important. In 1978 nearly $38 \%$ of medical school entrants were women and by 1985 this could rise to $50 \% .{ }^{1}$ This increasing proportion adds uncertainty to current attempts to plan medical manpower because little is known about which specialties women doctors now in training will enter as career posts and how many sessions they will work. ${ }^{2}$ There have been complaints of discrimination against women doctors ${ }^{3-6}$ and lack of part-time training posts, ${ }^{6-8}$ and career problems facing women doctors have been shown in several studies. ${ }^{8-10}$ The view has also been expressed, however, that a small proportion of women doctors complain excessively about their career problems while the majority are more usefully engaged in overcoming difficulties which are not insuperable. ${ }^{11}$

The Oxford Region was a pioneer in part-time training for married women doctors ${ }^{12}$ and is therefore a suitable place to evaluate part-time training, to assess the extent of other career problems, and to help determine further measures needed to ameliorate them. The present study tries to separate the influences on women doctors' careers of part-time work, being a woman, being a mother, and being married. The study also investigates the likely manpower contribution of women doctors and the need to create part-time career posts.

Oxford Regional Health Authority, Headington, Oxford OX3 7LF

A J SWERDLOW, MA, BM, senior registrar in community medicine

R H MCNEILLY, MD, FFCM, specialist in community medicine

E ROSEMARY RUE, FRCP, FFCM, regional medical officer

\section{Method and results}

In early 1979 a confidential questionnaire was sent to all 252 women doctors who were in postregistration training posts in the Oxford Region in December 1978. Names of hospital doctors in training were taken from the payroll and of general practice trainees from the regional general practice adviser. Community physician trainees were known to us personally. Non-respondents to the initial questionnaire were mailed again after one month, and those still non-respondent mailed again after a further month.

There were $231(92 \%)$ replies. About two-thirds of respondents were married $(68 \% *$ of hospital and community medicine doctors and $61 \%$ of those training for general practice); eight hospital and community medicine doctors and one training for general practice were widowed, divorced, or separated; the remainder were single (table I). Of those under 30, 55\% were married, compared with $72 \%$ of those aged 30 to 39 and $86 \%$ of those aged 40 or more. Over half $(61 \%)$ of the 154 married doctors had children, as did five of the nine widowed, divorced, or separated doctors. None of the 68 single doctors had children. A majority of the doctors with children $(59 \%)$ had at least one child aged under 5 . Ten married and one single respondent had adult dependants whom they looked after; eight of these 11 doctors also had children.

Almost half $(43 \%(97))$ of the respondents were graduates of London medical schools, few $(7 \%(15))$ were from Oxford clinical medical schools, $30 \%(68)$ were from other British medical schools, and $21 \%$ (48) were foreign graduates.

*Percentages throughout are of respondents to the relevant question.

TABLE I-Current posts by age and marital status

\begin{tabular}{|c|c|c|c|c|c|c|c|c|c|c|c|c|c|}
\hline & & \multicolumn{2}{|c|}{ Under 30} & \multicolumn{2}{|c|}{$30-34$} & \multicolumn{2}{|c|}{$35-39$} & \multicolumn{2}{|c|}{$40-44$} & \multicolumn{2}{|c|}{$45+$} & \multicolumn{2}{|c|}{ Total all ages } \\
\hline & & Married & $\underset{\text { married }}{\text { Not }}$ & Married & $\begin{array}{c}\text { Not } \\
\text { married }\end{array}$ & Married & $\begin{array}{c}\text { Not } \\
\text { married }\end{array}$ & Married & $\begin{array}{c}\text { Not } \\
\text { married }\end{array}$ & Married & $\begin{array}{l}\text { Not } \\
\text { married }\end{array}$ & Married & $\underset{\text { married }}{\text { Not }}$ \\
\hline \multicolumn{14}{|l|}{$\begin{array}{l}\text { Whole-time hospital and } \\
\text { community medicine: }\end{array}$} \\
\hline & .. & & & 3 & 5 & $\frac{1}{5}$ & 2 & 1 & & & 1 & 5 & 8 \\
\hline $\begin{array}{lll}\text { Registrar } & . . & \\
\text { SHO } & . .\end{array}$ & . & 21 & $\begin{array}{r}76 \\
26\end{array}$ & $\begin{array}{r}43 \\
13\end{array}$ & $\begin{array}{l}8 \\
4\end{array}$ & $\begin{array}{l}5 \\
3\end{array}$ & 3 & & & 1 & & 11 & 18 \\
\hline Whole-time general practice & “ & 16 & & & 8 & & & & & & & & \\
\hline $\begin{array}{l}\text { trainees } \\
\text { Part-time hospital and }\end{array}$ & .. & 16 & 10 & 1 & 4 & & & & & & & 17 & 14 \\
\hline $\begin{array}{l}\text { community medicine: } \\
\text { Senior registrar }\end{array}$ & .. & & -- & 5 & & 12 & & 2 & & 1 & & 20 & \\
\hline $\begin{array}{lll}\operatorname{Registrar} & \ldots & \\
\text { SHO } & . & .\end{array}$ & $\because$ & $\begin{array}{l}5 \\
4\end{array}$ & & $\begin{array}{l}4 \\
4\end{array}$ & 2 & $\begin{array}{l}5 \\
5\end{array}$ & & $\begin{array}{l}6 \\
4\end{array}$ & $\begin{array}{l}1 \\
1\end{array}$ & $\begin{array}{l}4 \\
3\end{array}$ & & ${ }_{20}^{25^{*}}$ & $\begin{array}{l}3 \\
1\end{array}$ \\
\hline Others $\because \because \quad \because \quad \quad \because$ & $\therefore$ & $i$ & & 1 & & & & 1 & 1 & 1 & & 4 & 1 \\
\hline $\begin{array}{l}\text { Part-time general practice } \\
\text { trainees }\end{array}$ & .. & 2 & 1 & 2 & & 3 & 1 & 1 & & & & 8 & 2 \\
\hline $\begin{array}{l}\text { appointment: } \\
\text { Hospital registrar }\end{array}$ & & & & 2 & & & & & & & & 2 & \\
\hline Hospital SHO & & 2 & & 1 & & 1 & & & & & & 4 & \\
\hline Total & .. & 53 & 44 & 40 & 23 & 35 & 6 & 15 & 3 & 10 & 1 & $154^{*}$ & 77 \\
\hline
\end{tabular}

*Includes one doctor age not known. 


\section{CURRENT POST}

One hundred and eight $\left(58^{\circ}\right)$ of the 187 hospital doctors, two of the three community medicine trainees, and $31(76 \%)$ of the 41 doctors training for general practice were working whole time when they replied to the questionnaire. Six doctors were not working when they replied (in three cases they were on maternity leave), and the remaining 84 were working part time. About half $(53 \%(75))$ of those working whole time were ever married, whereas all but two of those working part time were ever married (table II).

As would be expected the seniority of posts tended to rise with age (table I) among whole-time hospital doctors, and this was so for both married and unmarried doctors. Seniority tended to rise with age also for part-time doctors aged under 40, and an encouragingly large proportion had reached registrar and senior registrar grades. This was not the case, however, for doctors aged 40 and over, implying that some of them get stuck with their career progression $(32 \%(8)$ of those aged 40 and over were still SHOs).

TABLE II-Current sessions worked by marital and maternal status

\begin{tabular}{|c|c|c|c|c|c|}
\hline \multirow[b]{2}{*}{$\begin{array}{l}\text { Sessions } \\
\text { worked }\end{array}$} & \multirow[b]{2}{*}{$\begin{array}{l}\text { Never } \\
\text { married }\end{array}$} & \multicolumn{3}{|c|}{ Ever married } & \multirow[b]{2}{*}{ Total } \\
\hline & & $\begin{array}{l}\text { No } \\
\text { children }\end{array}$ & $\begin{array}{c}\text { Any children } \\
\text { aged under } \\
5\end{array}$ & $\begin{array}{l}\text { Children aged } 5 \\
\text { or more } \\
\text { but none younger }\end{array}$ & \\
\hline $\begin{array}{l}\text { Whole time } \\
\text { Part time: }\end{array}$ & 66 & 56 & 14 & 5 & 141 \\
\hline $\begin{array}{l}\text { six sessions } \\
\text { or less } \\
\text { Part time: }\end{array}$ & 2 & 2 & 26 & 19 & 49 \\
\hline $\begin{array}{l}\text { more than } \\
\text { six sessions } \\
\text { Part time: } \\
\text { number of } \\
\text { sessions }\end{array}$ & - & 4 & 12 & 17 & 33 \\
\hline $\begin{array}{c}\text { not stated } \\
\text { Not working }\end{array}$ & $=$ & $\overline{2}$ & $\begin{array}{l}2 \\
4\end{array}$ & 二 & $\begin{array}{l}2 \\
6\end{array}$ \\
\hline Total & 68 & 64 & 58 & 41 & 231 \\
\hline
\end{tabular}

further medical qualifications after graduating. Success in diploma examinations was unrelated to marital and maternal status but this was not the case for membership and fellowship examinations. Doctors with children at the time they sat these examinations more often failed $(49 \%$ of attempts were failures) than did those without children at the time they took the examinations $(30 \%$ of attempts were failures). Being married per se was not a bar to membership or fellowship examination success: the most successful group of doctors were married women with no children ( $20 \%$ of attempts were failures), whereas single doctors failed more often $(36 \%$ of attempts were failures). Only two respondents had obtained doctorates (one $M D$ and one DPHIL) but 45 had a master's or a bachelor's degree; 22 doctors stated they had a BSC or BA in preclinical medical sciences and six had qualifications in arts subjects.

\section{SPECIALTY CHOICE}

The doctors were asked about their career intentions and the considerations which had influenced these intentions. The most popular career choices (table III) were general practice $(23 \%)$, psychiatry $(14 \%)$, general medical specialties $(14 \%)$, anaesthetics $(11 \%)$, and pathology $(9 \%)$. The main influences leading to these choices (table IV) were the prospects for part-time careers and training, ability to get a training post and hours of work in the specialty, marital state, children, husband's career, and place of residence. Few doctors indicated that they were influenced by financial considerations or difficulty or ease of the examinations they would face in their chosen specialty.

For analysis, hospital specialties were divided into two groups on the basis of the pattern of responses in the study. "Group 1" consists of general medical specialties, paediatrics, surgery, and obstetrics and gynaecology. "Group 2" consists of pathology, psychiatry, anaesthetics, radiology, and radiotherapy. Those doctors wishing to enter group 1 were less concerned than other doctors about part-time career post opportunities, hours of work, and years of training required. Those aiming at group 2 specialties mentioned

TABLE III-Whole-time and part-time career intentions

\begin{tabular}{|c|c|c|c|c|c|c|c|c|c|}
\hline \multirow{3}{*}{\multicolumn{2}{|c|}{$\begin{array}{l}\text { Intended } \\
\text { career specialty }\end{array}$}} & \multicolumn{7}{|c|}{ No of sessions intended in career post } & \multirow{3}{*}{ Total } \\
\hline & & \multirow[t]{2}{*}{ Whole time } & \multicolumn{3}{|c|}{ Part time } & \multicolumn{3}{|c|}{ Part time, followed by whole time } & \\
\hline & & & 3-5 & $6-8$ & No not stated & 3-5 & $6-8$ & No not stated & \\
\hline \multirow{3}{*}{\multicolumn{2}{|c|}{ 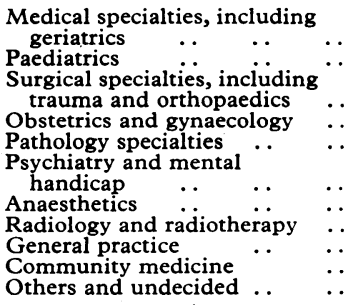 }} & $\begin{array}{l}9 \\
7\end{array}$ & $\begin{array}{l}1 \\
0\end{array}$ & $\begin{array}{l}9 \\
2\end{array}$ & $\begin{array}{l}1 \\
0\end{array}$ & $\begin{array}{l}0 \\
0\end{array}$ & $\begin{array}{r}11 \\
2\end{array}$ & $\begin{array}{l}2 \\
1\end{array}$ & $\begin{array}{l}33 \\
12\end{array}$ \\
\hline & & $\begin{array}{l}3 \\
9 \\
8\end{array}$ & $\begin{array}{l}0 \\
1 \\
2\end{array}$ & $\begin{array}{l}1 \\
0 \\
1\end{array}$ & $\begin{array}{l}0 \\
0 \\
0\end{array}$ & $\begin{array}{l}0 \\
1 \\
4\end{array}$ & $\begin{array}{l}2 \\
0 \\
5\end{array}$ & $\begin{array}{l}2 \\
2 \\
0\end{array}$ & $\begin{array}{c}8 \\
14^{*} \\
20\end{array}$ \\
\hline & & $\begin{array}{r}15 \\
11 \\
3 \\
24 \\
2 \\
6\end{array}$ & $\begin{array}{l}1 \\
1 \\
0 \\
3 \\
0 \\
0\end{array}$ & $\begin{array}{r}10 \\
2 \\
1 \\
2 \\
1 \\
5\end{array}$ & $\begin{array}{l}0 \\
3 \\
0 \\
1 \\
0 \\
0\end{array}$ & $\begin{array}{l}0 \\
1 \\
0 \\
7 \\
0 \\
3\end{array}$ & $\begin{array}{l}5 \\
1 \\
1 \\
6 \\
1 \\
3\end{array}$ & $\begin{array}{r}2 \\
7 \\
1 \\
11 \\
1 \\
3\end{array}$ & $\begin{array}{r}33 \\
26 \\
6 \\
54 \\
5 \\
20\end{array}$ \\
\hline Total ... & .. & 97 & 9 & 34 & 5 & 16 & 37 & 32 & $231^{*}$ \\
\hline
\end{tabular}

*Includes one doctor not stating whether whole time or part time intended.

\section{"ON-CALL" AND EXAMINATION RESULTS}

Though most respondents thought that their present post gave them sufficient on-call experience or that on-call experience was not relevant to their present work, 22 doctors (19 part timers and three doctors working whole time) thought that their present post did not offer sufficient on-call experience. These were all hospital doctors, mainly in medical (10) or laboratory (four) specialties; about half stated that they would be able to do weekend work (12) and night work (nine) were it offered. Most respondents said they were able to do night and weekend work. The great majority of those unavailable for on-call work were part timers $(86 \%(24)$ of those unavailable for nights or weekends) and were married with children $(86 \%(24)$ of those unavailable). Availability for on-call work did not seem to be affected by the age of the children $(25 \%$ of those with children under 5 and $30 \%$ of those with older children only were unavailable).

Seventy-one per cent (163) of respondents had attempted to gain particularly ability to get a training post as an influence on their choice, and they mentioned hours of work and part-time career opportunities more often than group 1 aspirants. General practice aspirants were less often influenced than other doctors by part-time training opportunities and more often influenced by part-time career opportunities, years of training and ease or lack of examinations required, hours of work, long-term financial prospects, and husband's career.

Thirty-three per cent (75) of the respondents stated that they had consciously changed their career plans because of home commitments; and sixty of them had originally wanted to enter group 1 specialties, with most changing to group 2 specialties or general practice. Reasons most often given for change of career choice were children $(56 \%)$, marital state $(51 \%)$, hours of work $(49 \%)$, and husband's career $(41 \%)$. Most $(88 \%)$ of those changing career choice were married. Women married to doctors changed their career intention less often because of home commitments $(35 \%)$ than did women married to laymen $(49 \%)$. Possibly this indicates greater 
tolerance by medical men than laymen of the problems of married women doctors.

Respondents were generally optimistic about their career prospects. When asked to indicate their chance of obtaining a career post in their intended career specialty only $18(8 \%)$ indicated this was "unlikely," $68(30 \%)$ indicated "moderately likely," and $138(62 \%)$ indicated "likely" or "very likely." Those making careers in surgery and in obstetrics and gynaecology were more pessimistic (realistically) than other respondents, but otherwise there were no appreciable differences between specialties. When asked which specialties they considered to be shortage specialties-that is, ones where career progression would be easier-respondents proved to be fairly well informed. Over half (of the 190 respondents) named geriatrics (56\%) and mental illness and mental handicap ( $54 \%$ ), and many mentioned anaesthetics $(48 \%)$, radiology $(42 \%)$, pathology $(23 \%)$, dermatology $(22 \%)$, and community medicine $(15 \%)$. careers. Doctors without children or with any children still aged under 5 had each on average contributed about four years' whole-time service, and this was true whether or not they had ever been off work or worked part time. Doctors with older children only, who had at some stage been off work or worked part time, had also on average worked four years whole time, but the four doctors with older children who had had uninterrupted whole-time careers had each contributed, on average, 11.5 years' whole-time service.

Doctors who had been in part-time employment were asked how it had affected their careers. A minority $(40 \%(34))$ thought that it had adversely affected senior doctors' attitudes towards them; most thought that it had adversely affected their ability to meet training requirements $(64 \%(55))$ and to apply for available posts $(71 \%(62))$. About one-fifth $(21 \%(48))$ of respondents were unaware of the Oxford regional part-time training scheme and one-third $(35 \%(81))$ were unaware of the national scheme. Most of these had no children

TABLE IV-Influences on career choice. (Figures are percentages of respondents indicating each influence)

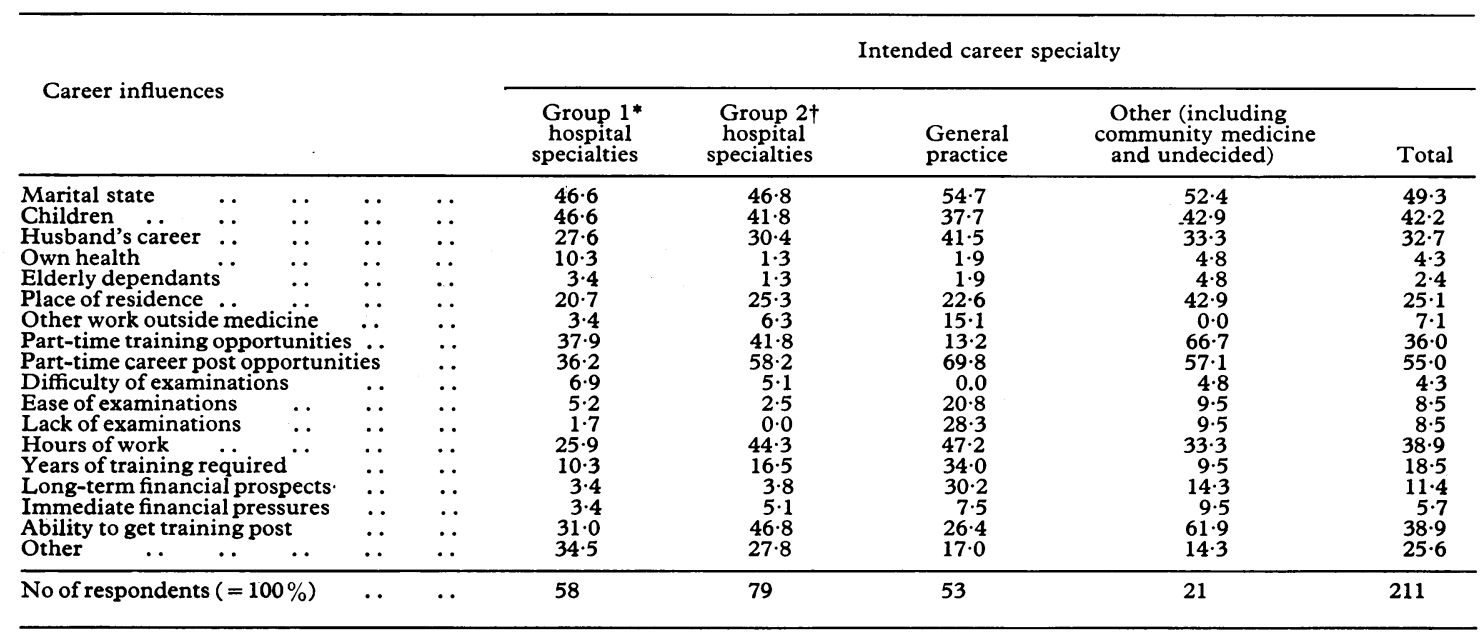

*Group I-General medical specialties, paediatrics, surgery, and obstetrics and gynaecology.

†Group II-Pathology, psychiatry and mental handicap, anaesthetics, radiology, and radiotherapy.

TABLE V-Whole-time and part-time work by marital and maternal status

\begin{tabular}{|c|c|c|c|c|c|}
\hline & $\begin{array}{c}\text { Never } \\
\text { married }\end{array}$ & $\begin{array}{l}\text { Ever married, } \\
\text { no children }\end{array}$ & $\begin{array}{l}\text { Ever married, } \\
\text { any children } \\
\text { now under } 5\end{array}$ & $\begin{array}{l}\text { Ever married, } \\
\text { children } 5 \\
\text { and over only }\end{array}$ & Total \\
\hline \multirow{6}{*}{$\begin{array}{l}\text { Number of doctors } \\
\text { Proportion of doctors } \\
\text { ever working part } \\
\text { time or off work } \\
\text { Mean years/doctor of } \\
\text { whole-time work } \\
\text { Mean years/doctor of } \\
\text { part-time work } \\
\text { Mean years/doctor } \\
\text { off work } \\
\text { Mean years/doctor } \\
\text { since qualification }\end{array}$} & $67^{*}$ & 64 & 58 & 41 & $230^{*}$ \\
\hline & $19 \cdot 4 \%$ & $31 \cdot 3 \%$ & $86 \cdot 2 \%$ & $90 \cdot 2 \%$ & $52 \cdot 2 \%$ \\
\hline & $4 \cdot 0$ & 3.5 & $4 \cdot 4$ & $4 \cdot 8$ & $4 \cdot 1$ \\
\hline & 0.1 & 0.1 & $2 \cdot 7$ & $7 \cdot 3$ & 2.0 \\
\hline & $0 \cdot 1$ & 0.1 & 0.5 & $3 \cdot 2$ & 0.7 \\
\hline & $4 \cdot 2$ & $3 \cdot 7$ & $7 \cdot 6$ & $15 \cdot 3$ & $6 \cdot 8$ \\
\hline
\end{tabular}

*Excludes one never-married doctor who did not reply to this question.

\section{PART-TIME CAREERS}

A third $(36 \%(84))$ of the respondents were working part time when they replied to the questionnaire and 39\% (89) had worked part time at some stage. Over half $(58 \%(133))$ hoped to get a part-time career post when they completed training, but the majority of these $(64 \%(85))$ wished to return to whole-time employment later in their careers (table III). Few $(19 \%(25))$ of those wanting part-time career posts initially wanted less than six sessions per week, while $53 \%(71)$ wished for six to eight sessions; the remainder did not specify the number of sessions they wanted.

Table $\mathrm{V}$ summarises the manpower contributions of respondents during their working lives to date. Most single doctors and married doctors without children had had uninterrupted whole-time work patterns; on average they had spent little time in part-time work or off work. Over four-fifths of doctors with children had worked part time or been off work for several months at some point in their and presumably did not currently need the schemes. But 24 doctors with children, who might well have required a period of part-time training, were unaware of the national part-time scheme, and 13 of these 24 doctors, as well as one doctor aware of the national scheme, were unaware of the Oxford scheme. Those mothers unaware of the scheme were not, as might have been expected, newly qualified doctors: all but one had been qualified at least five years and 10 had been qualified 10 years or more.

\section{INFLUENCE ON CAREERS}

Though few respondents $(12 \%(27))$ thought that the senior doctors for whom they had worked had been biased against them because they were women or married $(15 \%(24)$ of married respondents), a quarter of respondents with children $(27 \%(25))$ thought that the fact that they had children had been held against them. Only 
$12\left(6^{\circ}{ }_{0}\right)$ doctors thought that their sex had adversely affected their ability to meet training requirements but $29^{\circ}$ (45) of married respondents thought that being married had been a hindrance in this respect. Most of those with children $\left(74^{\circ}{ }_{0}(70)\right)$ thought that their children had been a handicap. While $23\left(11^{\circ} \mathrm{o}\right)$ doctors thought their sex adversely affected their ability to apply for available posts, over a third $(42 \%(66))$ of married doctors and over two-thirds of those with children $\left(73^{\circ}(69)\right)$ found their marital and maternal status, respectively, had been disadvantageous.

Other problems connected with children which were commonly mentioned were: difficulties in finding suitable part-time work, in arranging on-call rotas, and in studying; and the conflict between the demands of a career and the demands of motherhood. Problems volunteered in connection with marriage were difficulties in finding a suitable post in their area of residence, inability to move around the country to gain a variety of experience, and changes of job against career interests because of a move by the respondent's husband.

The 99 doctors with children were asked about arrangements they had made for care of their children while they were at work. Half $\left(51^{\circ}{ }_{0}(50)\right)$ had used a paid home help while their children were under 5 and almost two-thirds $\left(63^{\circ}{ }_{0}(39)\right)$ had done so for older children. Several had used childminders for under $5 \mathrm{~s}(17 \%(17))$ and a few had help from friends $\left(5^{\circ} \%(5)\right.$ for under $5 \mathrm{~s}, 11^{\circ}{ }_{\circ}(7)$ for older children). Many had used a nursery school $\left(43^{\circ}{ }_{0}\right)$ or crèche or playgroup $\left(33_{\%}^{\circ}\right)$ to look after under $5 \mathrm{~s}$; most $\left(85^{\circ},(53)\right)$ had used school for older children. Only a quarter had used relatives to look after their children $(23 \%$ for under $5 \mathrm{~s}, 29 \%$ for older children), presumably reflecting high geographical mobility of the doctors and their husbands in the early years of their professional careers.

An open question was asked about arrangements for child care needed by respondents but not available when they required them. The majority $(61 \%(60))$ of respondents currently wanted or had needed communal childminding facilities which were not available. A few needed or had needed domestic help $(6 \%(6))$ or financial help $(6 \%(6))$.

\section{Discussion}

The main career problems of women in medicine are not due to their sex but are problèms of conflicting loyalties and responsibilities-between career and husband and especially between career and children-and the reactions of senior doctors (generally men) to these problems. One reaction to these difficulties was that it is "best to put off marriage and children until fully trained." Another was "fuller discussion of likely problems before entering and while at medical school." Other frequently voiced themes were the need for greater understanding from men seniors and the need for changes in the systems of medical training and employment to allow the potential of women doctors to be utilised.

The study defined some problem areas where specific improvements could be made. The most severe career problems were those of part timers, particularly doctors with children under 5. Previous studies have also found particular career disadvantage for women doctors with children. ${ }^{9}$ Almost twothirds of the doctors with children needed or had needed communal childminding facilities that were not available. Provision of crèches or playgroups by employing authorities would enable women doctors with children to work and train more in the Health Service. Alternatively, some respondents thought that financial aid towards paying for child care would largely resolve the problem.

Other areas where health authorities might act are study leave and postgraduate education. Married doctors with children had more often failed higher examinations than had doctors without children, and some doctors with children described difficulty in studying as one of their career problems. Special study-leave arrangements may be needed for women doctors with children; the present Oxford part-time training scheme includes two sessions per week allocated for study. Night and weekend work is a further area where improvements could be made. Some doctors wanted more on-call experience than was offered in their current post-perhaps employing authorities should identify such doctors and, where possible, take advantage of their need for this experience.
As expected, part-time training was mainly confined to doctors with children; marital status in itself seemed of little relevance to the need for part-time work. Part-time training has worked successfully for many doctors; some respondents said they had moved to the Oxford Region because of its part-time training scheme and felt other regions should adopt similar programmes. The most notable problem about part-time training was the substantial number of doctors unaware of the schemes, particularly the national scheme. Several respondents commented on the lack of knowledge of personnel staff and district clinical tutors about part-time training and the need to publicise such schemes among medical students and doctors.

Some respondents commented on unsatisfactory experiences in part-time posts-for example, "one may easily become a sort of locum within the department, filling gaps, and doing least desirable jobs-not necessarily gaining very useful experience." The need for scrutiny of such posts was commented on; the Oxford Region operates a system of regular review of part-time training posts. Respondents recognised that part-time work, particularly with few sessions, is difficult to reconcile with the services needs of medicine and creates difficulties for wholetime colleagues, and that training may not be possible on very few sessions. There was, however, a desire for availability of part-time training, and of part-time work with few sessions, for the years of heavy domestic commitments-"women are much more likely to go back to full-time work later if they are encouraged and facilities are available for them to carry on parttime training while their families are young."

Doctors in part-time training said they valued being put in touch with others who had completed their training in this way. Other issues raised by respondents were the need for flexibility in part-time training schemes, for health authorities to show greater enterprise, and a desire for clear statements from the royal colleges of their arrangements for recognising part-time training. There seems to be a widespread desire for career posts which are initially part time but later whole time; creation of such posts might have particular appeal to employing authorities in the present period of financial stringency since they could provide a planned gradual increase in sessions and costs over several years.

\section{MANPOWER, CAREER PATTERNS, SPECIALTY CHOICE}

Several findings of the study were of value for manpower planning. Doctors with no children, whether or not they were married, had on average worked whole time for virtually all of their careers to date. But the great majority of doctors with children had not had uninterrupted whole-time careers. The usual manpower contribution to be expected from women doctors with children is about four years' whole-time work, followed by 10 or more years' part-time work (much of which would be less than six sessions per week) interspersed with periods off work totalling about four years, followed by wholetime or nearly whole-time work until retirement-that is, about a further 15 years' whole time). This totals roughly 24 years' whole-time-equivalent work in a professional lifetime.

The striking feature of this career pattern is that their major manpower contribution is in the final years before retirement. Thus it is particularly critical from an economic viewpoint that these final years should be spent working in a highly skilled and therefore valuable post. So it is important that the years of part-time service in the middle of married women doctors' careers should be regarded as postgraduate training. An adviser should be designated in each region to help with the particular career problems of women doctors. The number of doctors we identified who were still in SHO posts, though aged 40 or more, suggests the need for early help with career development. Such help is available in the Oxford Region.

The considerations which most influenced respondents' specialty choice, and the choices made, suggest that specialties wishing to attract many women doctors will have to construct 
training programmes that take account of the particular needs of women doctors with children. Specialty choice seemed to be more dependent on conditions of work and compatibility with married life and caring for children than on particularly feminine interest in the work. Home commitments were important influences on respondents' career choices and caused one-third of respondents to change their career choice (most changes being from group 1 specialties to group 2 or general practice). Comparatively few respondents were intending to enter the high-prestige specialties with much private practice, where competition is intense, hours of work often long, on-call commitment substantial, promotion slow, and examinations considered difficult. In contrast, many respondents intended to make careers in group 2 specialties, geriatrics, and general practice. These include the shortage specialties for which there is little competition (our respondents were well aware of this fact) and in which, therefore, training programmes are more likely to be flexible to the individual's needs, and in which hours of work, on-call commitment, and examinations are generally regarded as less arduous. The choice of group 2 specialties more often than group 1 is particularly striking when the work content of each is considered. Whereas group 1 specialties mean direct relationships with patients, much of group 2 is highly technological medicine with little or no continuing relationships with patients-for example, laboratory specialties, and to a less extent anaesthetics and radiology). The former type of work would probably generally be considered of more interest than the latter to most women. Group 1 specialties, which will need to attract more women doctors as the proportion of doctors who are women grows and the number of foreign graduates working in the National Health Service decreases, may have to provide training programmes which are more compatible with these doctors' family lives. A quarter of the respondents with children stated that they were not available for night and weekend work; training programmes in clinical specialties may therefore have to include the possibility of periods with no on-call commitment.

A further incentive to women doctors to enter particular specialties is remuneration, which was particularly important to respondents intending to enter general practice. In a previous study ${ }^{13}$ financial considerations were important to men doctors choosing general practice; presumably financial incentives could aid recruitment of both sexes to other specialties. Financial considerations also influence the extent to which women doctors work in medicine at all. As one doctor commented, "it is difficult to justify the nuisance value to the family of mother working if there is no financial benefit." The size of the medical manpower pool could probably be increased rapidly, were this desired, by greater financial incentives to work (either direct or via tax relief) for women doctors.

We thank Dr A Barr and Mr D Golding for helpful advice, Dr J C Hasler for supplying the names of trainees in general practice, Miss D James for clerical help, Mrs S Jones and Mrs N Cross for secretarial help, and the women doctors in training in the Oxford Region for their co-operation in the study.

\section{References}

${ }^{1}$ Royal Commission on the National Health Service. Report. London: HMSO, $1979: 221$.

2 Maynard A. Medical manpower in the year 2000. Br Med f 1979; :824.

${ }^{3}$ Bewley BR, Bewley TH. Hospital doctors' career structure and misuse of medical womanpower. Lancet 1975 ;ii :270-2.

4 Roberts S. All women are pregnant until proved otherwise. Lancet 1978;ii : 89-91.

5 A campaign to improve career prospects. Lancet 1979 ; :660-1.

6 Women doctors issue challenge. World Medicine $1979 ; 15: 21-3$.

7 Pickles H. Medical womanpower. Lancet 1979;ii :244.

${ }^{8}$ Lawrie JE, Newhouse ML, Elliott PM. Working capacity of women doctors. Br Med F 1966; :409-12.

${ }^{9}$ Beaumont B. Training and careers of women doctors in the Thames regions. $\mathrm{Br} \mathrm{Med} \mathcal{F} 1978 ; \mathrm{i}: 191-3$.

${ }^{10}$ Henryk-Gutt R, Silverstone R. Career problems of women doctors. Br Med F 1976;ii :574-7.

11 Savage A. Personal view. Br Med $\mathcal{F} 1980 ; 280: 177$.

12 Rue R. Employment of married women doctors in hospitals in the Oxford region. Lancet $1967 ; \mathrm{i}: 1267-8$.

13 Swerdlow AJ, Morris RJC, McNeilly RH. Career preferences of preregistration house officers in the Oxford region and secular trends in career choice. Health Trends 1979;11:38-41.

(Accepted 31 fuly 1980)

\title{
Survey of part-time senior registrar anaesthetists
}

\author{
JENNIFER M EATON
}

In 1960 less than $25 \%$ of medical school entrants were women. By 1978 this figure had risen to $37 \%$ and in some centres-for example, University of Bristol Medical School-it has now reached $50 \%$. A large percentage of these graduates will marry (roughly $80 \%$ in one recent survey ${ }^{1}$ ) and have children, and many will feel unable to continue in full-time employment at least for a time. The establishment of part-time posts in the training grades may allow such women to continue their careers. The Department of Health and Social Security has set out its most recent proposals for the part-time training (at SHO, registrar, and senior registrar level) of doctors with domestic commitments, disability, or ill-health in PM(79)3. ${ }^{2}$

Anaesthesia may be considered a "front-line" specialty in respect of part-time posts in that it is possible, to a certain extent at least, to organise the work load on a sessional basis. It is also a specialty which attracts relatively many women (about

Department of Anaesthetics, Royal United Hospital, Bath BA1 3NG

JENNIFER M EATON, MB, FFARCS, part-time senior registrar
$30 \%$ of senior registrars and $18 \%$ of consultant anaesthetists are women ${ }^{3}$.

The purpose of the present survey was to gather information from part-time senior registrar anaesthetists to assess the general pattern of their careers, the adequacy of their training, and their future aspirations.

In June 1979 a questionnaire was sent to the 35 part-time senior registrar anaesthetists enrolled with, but not yet accredited by, the Joint Committee for Higher Training of Anaesthetists (JCHTA). They were asked for an outline of their experience, their reasons for opting for part-time employment, the details of their present job, and their future plans. Comments on part-time training were also invited.

\section{Results}

Thirty-one questionnaires were returned (a response rate of $88.5 \%$ ) though two were incomplete: one respondent had not taken up her post and the other had only just started her job and felt unable to comment on it. All the respondents were women. Thirty were married and one was widowed. Twenty-six were between 30 and 39 